\title{
Assessment of Land Characteristics and Recommendation for Improvements in Patchouli Plantations in Aceh Province, Indonesia
}

Nasruddin, Khusrizal, Baidhawi, Muhammad Rusdi ${ }^{1}$

10.18805/IJARe.AF-674

\begin{abstract}
Background: Land characteristics and its criteria are important factors affecting the success of crop cultivation. This research aimed to evaluate the value and criteria of land characteristics for Aceh patchouli.

Methods: The study was conducted at smallholders' adopting patchouli farming in North Aceh (AU) and Gayo Lues (GL) using purposive sampling method. Eleven patchouli farming in both AU and GL were selected. Soil sampling and agroclimate data were collected from the farming.

Result: The results revealed that the altitude varied at each plantation and there were significant differences of altitudes, climates and soil characteristics between plantations in those two regions. It is found that the land characteristics in AU and GL of patchouli plantations are classified into marginally suitable (S3) and not suitable (N). But, the best class for patchouli lies between $\mathrm{S} 1-\mathrm{S} 3$, where S3 class requires adequate rainfall and organic- $C$, enabling the land to upgrade its class, to be resulted in an increase of patchouli production. The best patchouli growth and production was determined by land characteristics like base saturation (BS), total-N, erosion hazard, stoniness and rocks outcrop and have been evaluated and suitable suggestions were given.

Key words: Criteria of land characteristics, Land characteristics requirements, Land suitability class, Patchouli.
\end{abstract}

\section{INTRODUCTION}

Patchouli (Pogostemon cablin Benth) is considered as prospective aromatic plant for its essential oil. Indonesia is the world's largest producer of patchouli, $90 \%$ of global market in the world, contributing to the increase of national economy in Indonesia (Nasruddin et al., 2020). The demand of patchouli oil is increasing, as this oil has been used as fixative agent in cosmetic, perfume and soap industries. Unfortunately, the patchouli production in Indonesia still unable to meet the great demand of this commodity in global market as the production has continued to decrease in the last 4 years (Dirjenbun, 2018). Patchouli production varies between places in Indonesia. The highest was found in Sumatra Utara and Aceh Provinces. The data collected by Dirjenbun (2018) for the last 4 years (2014-2017) revealed the production in Sumatra Utara reached up $215.34 \mathrm{~kg} / \mathrm{ha} /$ year, followed by Aceh $(211.80 \mathrm{~kg} / \mathrm{ha} /$ year $)$ and other places (<140.00 kg/ha/year). Aceh patchouli oil demonstrated better quality compared to oil produced from patchouli in Sumatra Utara, enables Aceh patchouli to become more popular worldwide. Acehnese patchouli exhibited rendement 2-3\% and patchouli alcohol 30\%. These characteristics have lead Acehnese patchouli to be the main supplier of patchouli oil in Indonesia ( $\pm 70 \%$ ) (Ayu et al., 2016).

The oil production $211-215 \mathrm{~kg} / \mathrm{ha} /$ year is considered low. It is only $60 \%$ from the potential exhibited by Tapaktuan, Lhokseumawe and Sidikalang varieties, where they usually produce $375.76,355.89$ and $315.95 \mathrm{~kg} / \mathrm{ha} /$ year (Pujiharti et al., 2008). The oil production and quality are possible to be increased by evaluating its land characteristics, where
Program Study of Agroecotechnology, Faculty of Agriculture, Universitas Malikussaleh, Aceh Utara, Aceh, 24355, Indonesia. ${ }^{1}$ Remote Sensing and Cartography Lab, Universitas Syiah Kuala, Aceh, 23111, Indonesia.

Corresponding Author: Khusrizal, Program Study of Agroecotechnology, Faculty of Agriculture, Universitas Malikussaleh, Aceh Utara, Aceh, 24355, Indonesia. Email: khusrizal@unimal.ac.id

How to cite this article: Nasruddin, Khusrizal, Baidhawi and Rusdi, M. (2021). Assessment of Land Characteristics and Recommendation for Improvements in Patchouli Plantations in Aceh Province, Indonesia. Indian Journal of Agricultural Research. DOI: 10.18805/ IJARe.AF-674.

Submitted: 05-07-2021 Accepted: 22-10-2021 Online: 07-11-2021

these characteristics influence the patchouli growth, production and quality. Land characteristics for patchouli were released by Rosman et al. (1998) and Ministry of Agriculture (2014). However, these characteristics considered inadequate as they did not mention humidity, wet season, base saturation and nitrogen. Ritawati et al. (2019) and Setiawan et al. (2021) also did not mention base saturation and nitrogen. Temperature, rainfall, humidity and wet season play a crucial role in the plant growth and yield (Pugnaire et al., 2019). Base saturation and nitrogen are needed to be considered in land characteristics as they greatly influenced the plant growth and yield (Wahyunto et al., 2016). Base saturation represents soil fertility and nitrogen is important for plant physiology (Havlin et al., 2013; Gojon, 2017; Meshram et al., 2019). Therefore, we conducted this 
research to classify land suitability class for patchouli in $\mathrm{AU}$ and GL districts in order to establish the best land suitability for Acehnese patchouli.

\section{MATERIALS AND METHODS}

\section{Study area, time, tool and materials}

The research was conducted in September-November 2020 at smallholders' farming in AU and GL Regencies, Aceh Province, Indonesia (Fig 1). Geographically, the territory of $\mathrm{AU}$ stretch from $96^{\circ} .52^{\prime} .00^{\prime \prime}$ to $97^{\circ} .31^{\prime} 00^{\prime \prime} \mathrm{E}$ longitude and $04^{\circ} .46^{\prime} .00^{\prime \prime}$ to $05^{\circ} .00^{\prime} .40^{\prime \prime} \mathrm{N}$ at an altitude of $263-674 \mathrm{~m}$ asl, while GL stretch from $96^{\circ} .43^{\prime} .15 .65^{\prime \prime}$ to $7^{\circ} .55^{\prime} .24,29^{\prime \prime} \mathrm{E}$ longitude and $03^{\circ} .40^{\prime} .46,13^{\prime \prime}$ to $04^{\circ} .16^{\prime} .50 .45^{\prime \prime} \mathrm{N}$ at an altitude of $641-869 \mathrm{~m}$ asl.

The material used in this research for survey, soil analysis etc were $\mathrm{H}_{2} \mathrm{O}, \mathrm{HCl} 30 \%$, natrium pyrophosphate $\left(\mathrm{Na}_{4} \mathrm{P}_{2} \mathrm{O}_{7} 10 \mathrm{H}_{2} \mathrm{O}\right)$, distilled water, $\mathrm{K}_{2} \mathrm{Cr}_{2} \mathrm{O}_{7} 1 \mathrm{~N}$, concentrated $\mathrm{H}_{2} \mathrm{PO}_{4}, \mathrm{H}_{3} \mathrm{PO}_{7} 85 \%, \mathrm{FeSO}_{4} 1 \mathrm{~N}$ and $\mathrm{NH}_{4} \mathrm{OAc} 1 \mathrm{~N}$. The tools used were soil auger kit, hoe, machete, knife, bayonet knife, used magazines, compass, measuring tape, transparent plastic (size $1 \mathrm{~kg}$ ), labeled paper, GPS (Global position system), abney level, camera, stationery, computers and maps (land use map, administrative map, slope and soil maps).

\section{Data collection}

The data collected in this research was divided into primary and secondary data. Primary data described soil characteristics, patchouli growth (plant height, number of primary and secondary branches), oil production and quality (level of patchoulol). Secondary data showed us patchouli production of a soft production that lacks of leathery woods, collected by local farmers and staff from the Department of Agriculture and Plantation in those regencies, along with climatic data obtained from climate stations located in Malikussaleh, North Aceh and Indrapuri, Aceh Besar. Braak formula (1928) in Ritung et al. (2007): $\mathrm{T}=\mathrm{t}^{\circ} \mathrm{C}-\left(0.61^{\circ} \mathrm{C} \times \mathrm{h} \times\right.$ $0.01)$ was employed to estimate air temperature of selected research places.tis average temperature per year $\left(26.63^{\circ} \mathrm{C}\right)$, obtained from climate station Malikussaleh, North Aceh. This average temperature was used to forecast the temperature on the research sites. The identification of soil characteristics and its environment such as the elevation, soil depth, drainage, the slopes, the erosion hazard, stoniness and rocks outcrop were carried out at 22 patchouli plantations, 11 plantations in $A U$ (AU1-AU11) and 11 plantations in GL (GL1-GL11). Peat thickness, salinity, alkalinity and sulfidic depth were not assessed due to the land did not show those characteristics. Purposive sampling method was used in the selection of research site. The soil samples were taken from each plantation at a depth $0-30 \mathrm{~cm}$ using soil auger kit. All samples (22 samples) were air dried and then sieved using sieve $2 \mathrm{~mm}$ (10 mesh) to determine the physical properties of the soil such as soil texture 3 fraction (hydrometer) and the chemical properties such as soil $\mathrm{pH}(\mathrm{w} / \mathrm{s}: 2.5: 1)$ using pH meter (model WTW 330i/Germany), organic-C (Walkley and Black), total-N (Kjedahl), level of $\mathrm{P}_{2} \mathrm{O}_{5}$ (Extract $\mathrm{HCl} 25 \%$ ), level of $\mathrm{K}_{2} \mathrm{O}$ (Extract $\mathrm{HCl} 25 \%$ ), cation exchange capacityCEC $\left(\mathrm{NH}_{4} \mathrm{OAc} \mathrm{pH} \mathrm{7.0)}\right.$ and $\mathrm{BS}\left(\mathrm{NH}_{4} \mathrm{OAc} \mathrm{pH} 7.0\right)$ at Assessment Institute for Agricultural Technology (AIAT) Sumatra Utara.

\section{Determination of land suitability class}

The land suitability class was determined by matching the land characteristics of each plantation with the criteria of land suitability which has been modified and required by Rosman et al. (1998) and Ministry of Agriculture (2014). Nutrient retention of BS and total- $\mathrm{N}$ are considered as land characteristics influencing the growth and yield of patchouli specifically. Furthermore, the determination of the best land suitability for patchouli refers to land characteristics with the highest growth and yield. The developed criteria of land

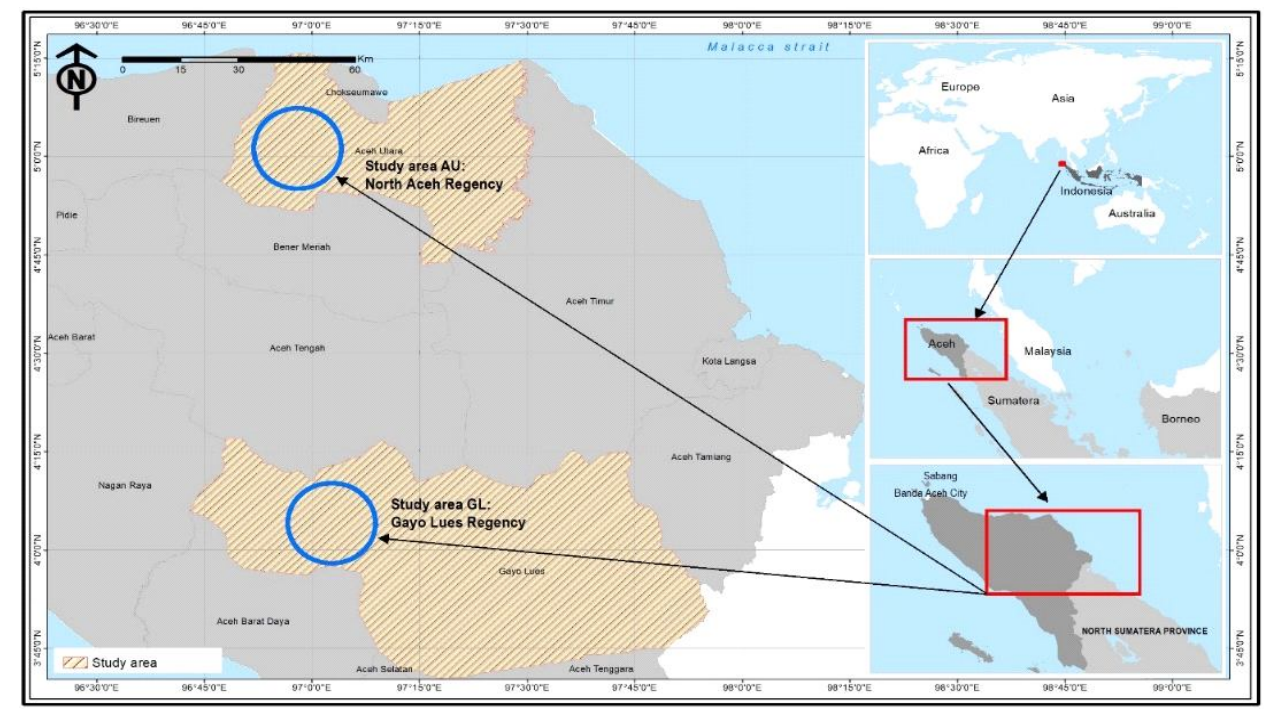

Fig 1: Map of study area. 
characteristics for patchouli have considered nutrient retention of BS and total-N as important aspects to be assessed.

\section{RESULTS AND DISCUSSION Land characteristics}

The results showed the differences on elevation, temperature, rainfall and wet season between $A U$ and $G L$. The plantations are located in lowland and highland (263$869 \mathrm{~m}$ asl), where average annual temperature is $25.03^{\circ} \mathrm{C}$. $\mathrm{AU}$ demonstrated higher temperature $\left(26.46^{\circ} \mathrm{C}\right)$ compared to $\mathrm{GL}\left(21.33^{\circ} \mathrm{C}\right)$, rainfall rate in $\mathrm{AU}$ is lower $(1490.3 \mathrm{~mm}$ ) compared to $\mathrm{GL}(1809.3 \mathrm{~mm})$. Also, the wet season in $A U$ is lower (8 months) compared to GL (11 months). However, both plantations have well to moderate drainage, dominated by sandy loam. Its soil depths are varied $(40-90 \mathrm{~cm})$. The shallowest $(40 \mathrm{~cm})$ was found in plantation AU9, AU10 and GL7, where this condition was found to be a constraint. Chemical, physical and biological properties in soil are important for plant growth, oxygen and nutrients availability (Fadlalla and Elsheikh, 2016; Meena et al., 2016).

CEC value varied between $4.55-30.99 \mathrm{cmol}(+) / \mathrm{kg}$, where the lowest found in $\mathrm{AU} 3$ and the highest in AU1. Base saturation was between $23.55-332.75 \%$, which the lowest found in GL8 and the highest in AU3. pH valued between 4.70-8.13, the lowest in GL8 and the highest in AU3. Organic- $C$ was between $0.94-5.47 \%$, where the lowest in AU3 and the highest in AU1. N, P, K elements also varied. $\mathrm{N}$ element was $0.06-0.50 \%$, where the lowest found in AU2 and the highest in AU1. P element was 4.02-33.86 ppm, where the lowest found in GL9 and the highest in GL3. K element was $0.25-1.86 \mathrm{me} / 100 \mathrm{~g}$, the lowest found in AU3 and the highest in AU6. The variety of characteristics found in the study site was influenced by parent material, low organic matter and intensive cultivation (Soares et al., 2005; Parikh and James, 2012). The slopes were between 5.24$16.73 \%$, the minimum in AU1, AU5, GL1 and GL2 and the maximum in GL10. Stoniness $<7 \%$ in AU2 and outcrop rocks $3 \%$ in AU9, AU10 and GL6.

\section{Classification of land suitability}

In this study, we classified land suitability through examining the data collected and modifying the established land suitability by Rosman et al. (1998) and Ministry of Agriculture (2014). The results were presented in Table 1, showing the land classes were marginally suitable (S3) and not suitable (N). S3 class demonstrated several limiting factors such as altitude, erosion hazard, temperature, water availability, root media and nutrient retention, while $\mathrm{N}$ class possessed erosion hazard, root media and nutrient retention as its

Table 1: Land suitability classes for patchouli in AU and GL Regencies.

\begin{tabular}{|c|c|c|c|c|}
\hline Site/Farm & Land suitability classes & Limiting factors & Land improvements & $\begin{array}{l}\text { Level of soil } \\
\text { improvement }\end{array}$ \\
\hline AU1 & S3wa-1 & Rainfall & Irrigation & $\mathrm{M}(+) ; \mathrm{H}(++)$ \\
\hline AU2 & S3wa-1,eh-1,na-1 & Rainfall,slope,N & Irrigation,SWC,N- fertilizer & $\mathrm{M}(+) ; \mathrm{H}(++)$ \\
\hline AU3 & Nnr-3 & $\mathrm{pH}$ & Liming & $\mathrm{M}(+) ; \mathrm{H}(++)$ \\
\hline AU4 & S3wa-1,eh-1,nr-4,na-1,2 & Rainfall;org-C;slope & Irrigation;OM;SWC; N and P- fertlizers & $\mathrm{M}(+) ; \mathrm{H}(++)$ \\
\hline AU5 & S3wa-1,nr-1,2,na-2,3 & Rainfall;CEC;BS;N;P & Irrigation;OM,liming, $\mathrm{N}$ and $\mathrm{P}$ - fertilizers & $\mathrm{M}(+) ; \mathrm{H}(++)$ \\
\hline AU6 & Neh-1 & Slope & SWC & $\mathrm{M}(+) ; \mathrm{H}(++)$ \\
\hline AU7 & S3wa-1,eh-1,na-2 & rainfall;slope;P & Irrrigation;SWC;P- fertilizer & $\mathrm{M}(+) ; \mathrm{H}(++)$ \\
\hline AU8 & S3rc-2,wa-1,eh-1, na-2 & Sd;rainfall;lope;P & Irrigation;SWC;P- fertilizer & $\mathrm{M}(+) ; \mathrm{H}(++)$ \\
\hline AU9 & $\mathrm{Nrc}-2$ & $\mathrm{Sd}$ & - & - \\
\hline AU10 & $\mathrm{Nrc}-2, \mathrm{nr}-3$ & $\mathrm{Sd} ; \mathrm{pH}$ & - & - \\
\hline $\mathrm{AU} 11$ & S3rc-2,wa-1,eh-1, & Sd;rainfall;slope & Irrigation,SWC & $\mathrm{M}(+) ; \mathrm{H}(++)$ \\
\hline GL1 & S3tc-1,nr-4 & Temperature;org-C & OM & $\mathrm{M}(+) ; \mathrm{H}(++)$ \\
\hline GL2 & S3rc-2,tc-1,nr-4,na-1 & Sd;temperature;org-C;N & OM; N- fertilizer & $\mathrm{M}(+) ; \mathrm{H}(++)$ \\
\hline GL3 & Nnr-3 & $\mathrm{pH}$ & Liming & $\mathrm{M}(+) ; \mathrm{H}(++)$ \\
\hline GL4 & S3el-1,tc-1,eh-1, na-1,2,3 & $\begin{array}{l}\text { Altitude;temperature; } \\
\text { slope, } \mathrm{N}, \mathrm{P}, \mathrm{K}\end{array}$ & SWC; N,P,K- fertilizers & $\mathrm{M}(+) ; \mathrm{H}(++)$ \\
\hline GL5 & S3el-1,tc-1,eh-1,nr-4,na-1,3 & $\begin{array}{l}\text { Altitude;temperatur; } \\
\text { slope;org-C,N,K }\end{array}$ & SWC;OM;N and K- fertilizers & $M(+) ; H(++)$ \\
\hline GL6 & S3el-1,tc-1,eh-1,nr-4,na-1,2 & $\begin{array}{l}\text { Altitude;temperature; } \\
\text { slope; org-C,N,P }\end{array}$ & SWC;OM;N and P- fertilizers & $M(+) ; H(++)$ \\
\hline GL7 & $\mathrm{Nrc}-2$ & $\mathrm{Sd}$ & - & - \\
\hline GL8 & Neh-1 & Slope & SWC & $\mathrm{M}(+) ; \mathrm{H}(++)$ \\
\hline GL-9 & Neh-1 & Slope & SWC & $M(+) ; H(++)$ \\
\hline GL10 & Neh-1 & Slope & SWC & $\mathrm{M}(+) ; \mathrm{H}(++)$ \\
\hline GL11 & S3el-1,tc-1,eh-1,na-1 & $\begin{array}{l}\text { Altitude; temperature; } \\
\text { slope; } \mathrm{N}\end{array}$ & SWC; N- Fertilizer & $M(+) ; H(++)$ \\
\hline
\end{tabular}

Notes: CEC -(cation exchange capacity); BS- (base saturation); N -(nitrogen); P- (phosphorus); K- (potassium); OM- (organic matter); SWC- (soil and water conservation technology ie silt pits, mounds; terrace); M- (moderate); H- (high); -- (hard to fix); + (land improvements can elevate the grade one level higher, S3 to S2); ++ (promotion to two levels higher, S3 to S1); Sd-Soil depth; pH-Soil pH. 
Assessment of Land Characteristics and Recommendation for Improvements in Patchouli Plantations in Aceh Province, Indonesia

Table 2: The data of growth, production and alcohol content of patchouli in AU and GL Regencies.

\begin{tabular}{|c|c|c|c|c|c|}
\hline \multirow{2}{*}{ Site/Farm } & \multirow{2}{*}{$\begin{array}{l}\text { Plant height } \\
\quad(\mathrm{cm})\end{array}$} & \multicolumn{2}{|c|}{ Number of branches } & \multirow{2}{*}{$\begin{array}{c}\text { Oil product } \\
\left(\mathrm{kg} \mathrm{ha}^{-1} \text { year }^{-1}\right)\end{array}$} & \multirow{2}{*}{$\begin{array}{l}\text { Content of } \\
\text { alcohol (\%) }\end{array}$} \\
\hline & & Primary & Secondary & & \\
\hline$\overline{\mathrm{AU} 1}$ & 94.33 & 7 & 25 & 240 & 30.43 \\
\hline AU2 & 91.33 & 13 & 43 & 230 & 31.92 \\
\hline AU3 & 102 & 18 & 45 & 225 & 30.78 \\
\hline AU4 & 114.3 & 10 & 56 & 233 & 33.26 \\
\hline AU5 & 81.67 & 9 & 67 & 235 & 31.89 \\
\hline AU6 & 98.33 & 8 & 56 & 229 & 33.36 \\
\hline AU7 & 80.67 & 9 & 29 & 235 & 32.54 \\
\hline AU8 & 89.33 & 6 & 51 & 232 & 33.23 \\
\hline AU9 & 98.67 & 9 & 67 & 219 & 31.79 \\
\hline AU10 & 101 & 9 & 51 & 221 & 33.23 \\
\hline AU11 & 95.17 & 10 & 64 & 237 & 32.24 \\
\hline GL1 & 85 & 16 & 49 & 345 & 29.84 \\
\hline GL2 & 75 & 19 & 49 & 348 & 30.01 \\
\hline GL3 & 85.67 & 16 & 86 & 340 & 29.78 \\
\hline GL4 & 85.67 & 6 & 39 & 348 & 28.98 \\
\hline GL5 & 66.67 & 11 & 65 & 348 & 29.75 \\
\hline GL6 & 100 & 18 & 65 & 347 & 28.39 \\
\hline GL7 & 51.67 & 9 & 24 & 332 & 28.45 \\
\hline GL8 & 101.7 & 11 & 32 & 343 & 28.78 \\
\hline GL9 & 80.67 & 7 & 15 & 340 & 30.01 \\
\hline GL10 & 78.67 & 14 & 53 & 339 & 29.45 \\
\hline GL11 & 81.07 & 17 & 56 & 348 & 29.34 \\
\hline
\end{tabular}

limiting factors. In $\mathrm{AU}$, patchouli planted at S3 class experienced slope, rainfall, organic- $\mathrm{C}, \mathrm{pH}$ and $\mathrm{CEC}$, while at $\mathrm{N}$ class, the plants experienced slope, soil depth and $\mathrm{pH}$. In GL, S3 class exhibited several limiting factors such as altitude, temperature, slope and organic- $\mathrm{C}$, while $\mathrm{N}$ class demonstrated similar condition shown in AU. Altitude, temperature and soil depth are un-improvable. Soil slopes in $A U$ and $G L$ have been improved through applying soil conservation by building silt pits and mounds and planting avocado. Therefore, the $\mathrm{N}$ classes in $\mathrm{GL}$ possessed with slope did not affect the patchouli growth and yield. Similar phenomenon also occurs in S3 classes in $\mathrm{AU}$ and $\mathrm{GL}$ where at slope $<25 \%$ there is possibility to cultivate crops as the conservation applied properly to support the plant growth (Chen et al., 2020).

CEC and organic-C in S3 class in study sites observed were improved by applying organic matter. However, it needs to be increased and continued to optimize the organic matter in the soil. Organic matter significantly improves the soil's capacity to store and supply essential nutrients and carbon and also it enhances CEC and water infiltration (Havlin et al., 2013).

\section{Value of land characteristics for patchouli plantation}

The growth, production and the quality of patchouli oil were determined by the value of land characteristics for patchouli (Table 2), where the best and highest growth, production and quality of patchouli oil were often found in lands with distinctive characteristics. The land characteristics and values were presented in Table 3.
Table 3: Land characteristics and Index values for patchouli plantation.

\begin{tabular}{ll}
\hline Land characteristics & Index values \\
\hline Altitude $(\mathrm{m}$. a.s.l) & $326-644$ \\
Annual temperature average $\left({ }^{\circ} \mathrm{C}\right)$ & $22.72-25.03$ \\
Annual rainfall average $(\mathrm{mm})$ & $1809.3-1490.3$ \\
Wet month & $3-11$ \\
Humidity (\%) & $82.22-86.66$ \\
Drainage & Well drainage, -moderate \\
Soil texture & Sandy loam, loamy \\
Soil depth (cm) & $>80$ \\
Cation exchange capacity $(\mathrm{cmol}(+) / \mathrm{kg})$ & $12,21-30,99$ \\
Base saturation (\%) & $80-100$ \\
Soil pH $\mathrm{H}_{2} \mathrm{O}$ & $6.14-6,63$ \\
Organic-C (\%) & $1.58-5.47$ \\
Total- $\mathrm{N} \mathrm{( \% )}$ & $0.24-0.53$ \\
$\mathrm{P}_{2} \mathrm{O}_{5}$ (ppm) & $18.41-24.39$ \\
$\mathrm{~K}_{2} \mathrm{O}(\mathrm{me} / 100 \mathrm{~g})$ & $0.76-1.93$ \\
Slope $(\%)$ & $<5.24$ \\
Erosion hazard & Very light, -moderate \\
Stoniness $(\%)$ & $5-17$ \\
Rock outcrops (\%) & $3-12$ \\
\hline
\end{tabular}

Data in Table 4 presented the best land characteristics required for patchouli in $\mathrm{AU}$ and $\mathrm{GL}$. Each characteristic was classified into S1, S2 and S3 classes. The land in S3 class was characterized by its rainfall $1490.3 \mathrm{~mm}$ which found $\mathrm{AU}$ plantations, where it is possible to be improved by irrigation, silt pits forming, bio-pores and retention basin to maximize water availability in the soil. The water is essential for nutrient 
Assessment of Land Characteristics and Recommendation for Improvements in Patchouli Plantations in Aceh Province, Indonesia

absorption, biota activities and plant physiology (Razaq et al., 2017; Weih et al., 2018). The organic-C 1.58\% found in GL1 also has been fixed by the provision of organic matter in the soil, resulting in an increased yield from $316 \mathrm{~kg} / \mathrm{ha} /$ year to $375 \mathrm{~kg} / \mathrm{ha} /$ year. Organic-C is also crucial for enhancing soil properties, attributed to soil fertility and productivity (Jacoby et al., 2017; Johns, 2017; Elayaraja and Sathiyamurthi, 2020).

Table 4: Criteria of land suitability classification for patchouli.

\begin{tabular}{|c|c|c|c|c|}
\hline \multirow{2}{*}{ Land qualities/Land characteristics } & \multicolumn{4}{|c|}{ Land suitability classes } \\
\hline & S1 & S2 & S3 & $\mathrm{N}$ \\
\hline \multicolumn{5}{|l|}{ Elevation (el) } \\
\hline Altitude (m. a.s.l) & $100-400$ & $0-100 ; 400-700$ & $700-800$ & $>800$ \\
\hline \multicolumn{5}{|l|}{ Temperature (tc) } \\
\hline Annual rainfal average $\left({ }^{\circ} \mathrm{C}\right)$ & $22-23$ & $24-25$ & $19-21$ and26-27 & $<19$ and $>27$ \\
\hline \multicolumn{5}{|l|}{ Water availability (wa) } \\
\hline Annual rainfall average $(\mathrm{mm})$ & $2.300-3.000$ & $1.750-2.300$ & $1.200-1.750$ & $<1.200$ \\
\hline Wet season (month) & 10-11 & 8-9 & 7 & $<7$ \\
\hline Humidity (\%) & $80-90$ & $70-80$ & $50-60$ & $<50$ \\
\hline \multicolumn{5}{|l|}{ Oxygen avaibility (oa) } \\
\hline Drainage & Well & Moderate & Poorly & Very poorly \\
\hline \multicolumn{5}{|l|}{ Root retention (rc) } \\
\hline Soil texture & I; scl; sicl & $\mathrm{sc} ; \mathrm{cl}$ & sic;sl & $\mathrm{s} ; \mathrm{c}$ \\
\hline Soil depth $(\mathrm{cm})$ & $>100$ & $75-100$ & $50-75$ & $<50$ \\
\hline \multicolumn{5}{|l|}{ Nutritions retention (nr) } \\
\hline CEC $(\mathrm{cmol}(+) / \mathrm{kg})$ & $>17$ & $6-17$ & $<6$ & - \\
\hline Base saturation (\%) & $>80$ & $51-80$ & $20-50$ & $<20$ \\
\hline Soil $\mathrm{pH} \mathrm{H} \mathrm{H}_{2} \mathrm{O}$ & $5.5-7.0$ & $5.0-5.4$ & $4.5-4.9$ & $<4.5$ \\
\hline Organic-C (\%) & $2.0-3.0$ & $3.1-5.0$ & $1.0-1.9$ & $<1.0$ \\
\hline \multicolumn{5}{|l|}{ Nutritions availability (na) } \\
\hline Total-N (\%) & $0.51-0.75$ & $0.31-0.50$ & $0.21-0.30$ & $<0.21$ \\
\hline $\mathrm{P}_{2} \mathrm{O}_{5}(\mathrm{ppm})$ & $15-25$ & 10-15 & $>25$ & - \\
\hline $\mathrm{K}_{2} \mathrm{O}(\mathrm{me} / 100 \mathrm{~g})$ & $>1.0$ & $0.6-1.0$ & $0.2-0.5$ & $<0.2$ \\
\hline \multicolumn{5}{|l|}{ Erosion hazards (eh) } \\
\hline Slope (\%) & $0-2$ & $2-8$ & $8-15$ & $>15$ \\
\hline Erosion hazard & Very light & Light-moderate & Heavy & Very heavy \\
\hline \multicolumn{5}{|l|}{ Land preparation (Ip) } \\
\hline Stoniness (\%) & $<5$ & $5-12$ & $12-35$ & $>35$ \\
\hline Rock outcrops (\%) & $<5$ & $5-12$ & $12-25$ & $>25$ \\
\hline
\end{tabular}

Note: I (loam); scl (sandy clay loam); sicl (silt clsy loam); sc (sandy clay); cl (clay loam); sl (sandy loam); s (sand); c (clay).

Table 5: Correlation between land characteristics and patchouli growth and yield.

\begin{tabular}{|c|c|c|c|c|c|c|}
\hline \multirow{2}{*}{ Land characteristics } & \multicolumn{6}{|c|}{ Growth and yield of patchouli } \\
\hline & Y1 & Y2 & Y3 & Y4 & Y5 & Y6 \\
\hline Altitude (m.asl) & -.31 & $.44^{*}$ & .04 & -.04 & $-.71^{* *}$ & $.68^{* *}$ \\
\hline Temperature $\left({ }^{\circ} \mathrm{C}\right)$ & .31 & $-.44^{*}$ & -.04 & .04 & $.71^{* *}$ & $-.68^{* *}$ \\
\hline Rainfall (mm/year) & $.52^{*}$ & $.47^{*}$ & .38 & -.09 & $-.87^{\star *}$ & $.87^{* *}$ \\
\hline Humidity (\%) & $.52^{*}$ & $.47^{*}$ & .38 & -.09 & $-.87^{\star *}$ & $.87^{* *}$ \\
\hline Wet season (moon) & $.52^{*}$ & $.47^{*}$ & .38 & -.09 & $-.87^{\star *}$ & $.87^{* *}$ \\
\hline Sand & -.13 & .15 & .06 & -.38 & $-.45^{*}$ & .34 \\
\hline Silt & .27 & .21 & .06 & .32 & $.44^{*}$ & -.26 \\
\hline $\operatorname{CEC}(\mathrm{cmol}(+) / \mathrm{kg})$ & .05 & .33 & $.55^{\star *}$ & .21 & .18 & .08 \\
\hline Organic-C (\%) & .03 & .28 & $.65^{\star *}$ & .01 & .26 & .24 \\
\hline $\mathrm{pH}$ & .26 & $.48^{*}$ & $.52^{*}$ & .22 & .07 & .04 \\
\hline Total-N(\%) & .03 & .43 & $.57^{*}$ & .02 & .28 & .19 \\
\hline $\mathrm{P}_{2} \mathrm{O}_{5}(\mathrm{ppm})$ & .13 & $.77^{* *}$ & .40 & .29 & .34 & $.54^{*}$ \\
\hline Stoniness (\%) & .21 & -.25 & .03 & -.15 & .17 & $-.49^{*}$ \\
\hline Rock outcrop (\%) & -.40 & .01 & .01 & .10 & .11 & $-.43^{*}$ \\
\hline
\end{tabular}

Note : * Significant at 0.01 ; 'Significant at $0.05 ; \mathrm{Y} 1=$ plant height; $\mathrm{Y} 2=$ number of leaves; $\mathrm{Y} 3=$ Number of primary branches; $\mathrm{Y} 4=$ Number of secondary branch; $Y 5=$ Patchouli alcohol; $Y 6=$ Productivity. 
Recommendation of criteria of land characteristics requirement for patchouli plantation

We were trying to enhance the land characteristics required for patchouli plantation, where these indicators were a modification from land suitability requirement released by Rosman et al. (1998) and Ministry of Agriculture (2014) with adjusting several suitable characteristics such as altitude, temperature, wet season, drainage, soil texture and formation, soil depth, CEC, $\mathrm{pH}$ and organic-C. We also considered $\mathrm{BS}$, total- $\mathrm{N}$, the erosion hazard, stoniness and rock outcrops to be assessed.

The modified and improved land characteristic requirements for patchouli was revealed in Table 4, where the requirements have been appointed based on this research in the sites, the correlation between land characteristics and patchouli growth and yield (Table 5) and also the evaluation of soil fertility at the plantation. The land characteristics we assessed from each land suitability class attributed to the growth and yield of patchouli.

\section{CONCLUSION}

The elevation and climate varied with plantations and showed differences between the plantations $A U$ and $G L$, where patchouli has been grown in highlands (>700 $\mathrm{m}$ asl) in GL. That contributed to differences in land characteristics and $A U$ and $G L$.

Land suitability in $A U$ and GL was classified into S3 (marginally suitable) and $\mathrm{N}$ (not suitable). $\mathrm{N}$ class was found at AU6, AU9 and AU10, while in GL was found at GL3, GL7, GL8, GL9 dan GL10. The plantations with maximum slope (GL8, GL9 and GL10) have been upgraded using conservation technology, while in AU (AU9 and AU10), its soil depth was unfixable. The $\mathrm{pH}$ value in GL3 has been lowered through application of organic matter.

The best criteria and land indicators in Aceh were laid between S1-S3 classes with implementation of land improvements. However, this study offers scope for further improvements by adding base saturation, total- $\mathrm{N}$, the erosion hazard, stoniness and rockoutcrops as essential land characteristics to ensure higher production of patchouli oil.

\section{REFFERENCES}

Ayu, P.K., Wijana, S. and Utomo, E.P. (2016). Design of medium scale-integrated patchouli oil agro-industry in east java. Jurnal Pembangunan dan Alam Lestari (J-PAL). 7(1): 68-75.

Chen, X., Liang, Z., Zhang, Z. and Zhang, L. (2020). Effects of soil water conservation measures on runoff and sediment yield in red soil slope farmland under natural rainfall. Suistainability. 12(3417): 1-9. doi: 10.3390/su1208 3417.

Dirjenbun (2018). Patchouli Road Map 2018-2024. Directorate General of Plantation, Ministry of Agriculture of the Republic of Indonesia. Jakarta (In Indonesian).
Elayaraja, D. and Sathiyamurthi, S. (2020). Influence of organic manures and micronutrients fertilization on the soil properties and yield of sesame (Sesamum indicum L.) in coastal saline soil. Indian Journal Agricultural Research. 54(1): 89-94.

Fadlalla, R. and Elsheikh, A. (2016). 2016. Physical land suitability assesment based on FAO framework. IOSR Journal of Engineering (IOSRJEN). 6(12): 36-44.

Gojon, A. (2017). Nitrogen nutrition in plants: Rapid progress and new challenges. J. Exp. Bot. 68(10): 2457-2246. doi:10.1093/jxb/erx171.

Havlin, J.L., Tisdale, S.L., Nelson, W.L. and Beaton, J.D. (2013). Soil Fertility and Fertilizers: An Introduction to Nutrient Management. ( $7^{\text {th }}$ Edition ed.): Pearson Educational, Inc. Upper Saddle River, New Jersey.

Jacoby, R., Peukert, M., Succurro, A., Koprivova, A. and Kopriva, S. (2017). The role of soil microorganisms in plant mineral nutrition - Current Knowledge and Future Directions. Front Plant Sci. 8(1617). doi: 10.3389/fpls.2017.01617.

Johns, C. (2017). The Role of Carbon in Promoting Healthy Soils. Strateggic Analysis Paper. Paper presented at The principle reference for this Strategic Analysis Paper is Soil Organic Carbon: The Hidden Potential, FAO, Rome, 18 May 2017.

Meena, S., Swaroop, N. and Dawson, J. (2016). Effect of integrated nutrient management on physical and chemical properties of soil. Agricultural Science Digest. 36(1): 56-59.

Meshram, N., Ismail, S., Shirale, S. and Patil, V. (2019). Impact of Long-term fertilizer application on soil fertility, nutrient uptake, growth and productivity of soybean under soybeansafflower cropping sequence in Vertisol. Legume ResearchAn International Journal. 42(2): 182-189.

Ministry of Agriculture. (2014). Technical Guidelines for Patchouli Cultivation (Regulation of the Minister of Agriculture of the Republic of Indonesia, Number 138 of 2014). Ministry of Agriculture Republic of Indonesia. Jakarta (In Indonesian).

Nasruddin, Harahap, E.M., Hanum, C. and Siregar, L.A.M. (2020). Enhancement of drought tolerance in patchouli (Pogostemon cablin, Benth) by modifying micro climate and frequency of fertilizer. Indian Journal Agricultural Research. 54(2): 501-505.

Parikh, S.J. and James, B.R. (2012). Soil: The Foundation of Agriculture. Nature Education Knowledge. 3(10): 2.

Pugnaire, F.I., Morillo, J.A., Penuelas, J., Reich, P.B., Bardgett, R.D., Gaxiola, A., Wardle, D.A. and Van der Putten, W.H. (2019). Climate change effects on plant-soil feedbacks and consequences for biodiversity and functioning of terrestrial ecosystems. Science Advance. 5(11): 1-11. doi: 10.1126/sciadev.aaz1834.

Pujiharti, Y., Mustikawati, D.R. and Slameto. (2008). Patchouli Cultivation Technology. In: Indonesian Center for Agricultural Technology Assessment and Development. [Kiswanto, B. Wijayanto and A. Soim (Eds.)], Indonesian Agency for Agricultural Research and Development. Lampung. (In Indonesian).

Razaq, M., Zhang, P., Shen, H.I. and Salahuddin (2017). Influence of nitrogen and phosphorous on the growth and root morphology of Acer mono. PLoS One. 12(2): 1-13. doi: 10.1371/journal.pone.0171321. 
Ritawati, S., Utama, P., Pancaningsih, E. and Ismawati. (2019). Evaluation of land suitability for cultivation of java patchouli (Pogostemon heyneanus, Benth) in the dry land of northern Serang, Banten province. IOP Conference Series: Earth and Environmental Science. 383: 012045. doi: 10.1088/ 1755-1315/383/1/012045

Ritung, S., Wahyunto, Agus, F. and Hidayat, H. (2007). Land suitability evaluation guide with example of land use direction map for West Aceh District. Bogor: Indonesian Soil Research Institute and World Agroforestry Centre (ICRAFT). Bogor, Indonesia (In Indonesian).

Rosman, R., Emmyzar and Wahid, P. (1998). Land and climate characteristics for development zoning Patchouli Monograph. Indonesian Spice and Medicinal Crops Research Institute. Bogor (In Indonesian). (Vol. 5, pp. 47-54).

Setiawan, A., Armita, D., Rahayu, A. P. and Barunawati, N. (2021). Assessing and evaluating land suitability in the development of patchouli (Pogostemon cablin) effect on patchouli essential oil. Biotropia-The Southeast Asian Journal of Tropical Biology. 28(1): 74-83. doi:10.11598/btb.2021. 28.1.1092.

Soares, J.L.N., Espindola, C.R. and Pereira, W.L.M. (2005). Physical properties of soils under intensive agricultural management. Scientia Agricola. 62: 165-172.

Wahyunto, Hikmatullah, Suryani, E., Tafakresnanto, C., Ritung, S., Mulyani, A., Sukarman et al. (2016). Technical Guidelines for Land Suitability Guidelines for Strategic Commodities Semi-Detailed Scale 1:50.000: Indonesian Agency for Agricultural Research and Development, Bogor (In Indonesian).

Weih, M., Hamnér, K. and Pourazari, F. (2018). Analyzing plant nutrient uptake and utilization efficiencies: comparison between crops and approaches. Plant and soil. 430(1): 7-21. doi: 10.1007/s11104-018-3738-y. 